\title{
Nutritional value and inclusion levels of residual annatto seed meal in diets for Japanese quails
}

\author{
Valor nutricional y niveles de inclusión de harina residual de semilla de achiote en dietas para codorniz \\ Japonesa
}

\section{Valor nutritivo e níveis de inclusão do farelo residual da semente de urucum em dietas para codornas Japonesas}

\author{
Iana Pimentel-Mani ${ }^{1}$ D ; Maria C Oliveira ${ }^{2 *}$ id ; Sarah CO Lima-Dóro ${ }^{2}$ iD; Poliana Carneiro-Martins ${ }^{3}$ (D); Marcos AP \\ Souza-Júnior ${ }^{3}$ iD. \\ ${ }^{1}$ Instituto Federal Goiano, Rodovia Sul Goiana, Km 01, s/n, 75.901-970 Rio Verde, GO, Brazil. \\ ${ }^{2}$ Faculdade de Medicina Veterinária, Universidade de Rio Verde, 75.901-910 Rio Verde, GO, Brazil. \\ ${ }^{3}$ Universidade Federal de Goiás, 74.690-900 Goiânia, GO, Brazil.
}

To cite this article:

Pimentel-Mani I, Oliveira MC, Lima-Dóro SCO, Carneiro-Martins P, Souza-Júnior MAP. Nutritive value and inclusion levels of residual annatto seed meal in dietsof Japanese quails. Rev Colomb Cienc Pecu 2020; 33(2): 110-120.

DOI: https://doi.org/10.17533/udea.rccp.v33n2a03

\begin{abstract}
Background: Residual annatto seed meal (RASM) is a byproduct after extraction of bixin in the cosmetic industry and may be used in animal diets. Objective: Two experiments were carried out to determine the nutritive value and effect of RASM inclusion levels in the diets of Japanese quails. Methods: For the digestibility experiment, 160 Japanese quails were distributed in a randomized study with two treatments and 10 replicates with eight birds each. The treatments consisted of a reference diet and a test diet containing $75 \%$ of the reference diet and $25 \%$ of RASM. For the performance assay, 192 Japanese quails were used in a randomized study with six treatments and four replicates with eight birds each. Treatments consisted of a control corn-based diet (Contr1) and another diet based on sorghum + canthaxanthin (Contr2), and four diets based on sorghum with increasing inclusion levels of RASM $(0,3,6$, and 9\%). Results: Digestibility of dry matter and crude protein, metabolization coefficient of gross energy, and retention of calcium and phosphorus were $41.05,43.12,47.97,25.49$, and $30.35 \%$, respectively. RASM inclusion did not influence bird productivity; however, feed conversion worsened in treatments with 0-6\% RASM inclusion relative to that in Contr1. Yolk color increased due to RASM treatment. Conclusion: RASM may be included in sorghum-based diets for quails at $9 \%$, with improvement in yolk color and no negative effects on productivity and egg quality.
\end{abstract}

Keywords: annatto seed; Bixa Orellana; Coturnix japonica; egg; egg quality; feed byproducts; Japanese quail; nutrient digestibility; plant pigment; poultry nutrition; yolk pigmentation.

Received: January 19, 2018; accepted: August 23, 2019

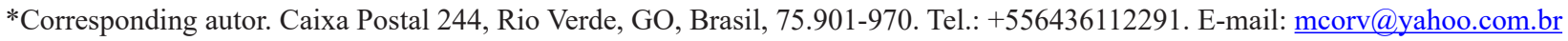




\section{Resumen}

Antecedentes: La harina de la semilla de achiote (RASM) es un subproducto de la extracción de bixina por la industria cosmética y puede ser usada en alimentación animal. Objetivo: Se realizaron dos experimentos para determinar el valor nutritivo y los efectos de la inclusión de RASM en dietas para codorniz. Métodos: Para el experimento de digestibilidad, 160 codornices japonesas fueron distribuidas en un estudio al azar con dos tratamientos y 10 repeticiones con ocho aves cada uno. Los tratamientos consistieron en una dieta referencia y una dieta de prueba, la cual estuvo compuesta por $75 \%$ de la dieta referencia y $25 \%$ de RASM. Para el ensayo de desempeño, 192 codornices japonesas fueron usadas en un estudio al azar con seis tratamientos y cuatro repeticiones con ocho aves cada uno. Los tratamientos consistieron en una dieta control a base de maíz (Contr1) y otra a base de sorgo + cantaxantina (Contr2) y cuatro dietas a base de sorgo con niveles de inclusión de RASM $(0,3,6$ y 9\%). Resultados: Los coeficientes de digestibilidad de materia seca y proteína bruta, el coeficiente de metabolización de la energía bruta y la retención de calcio y fósforo fueron 41,$05 ; 43,12 ; 47,97 ; 25,49$ y 30,35\%, respectivamente. La inclusión de RASM no influyó la productividad de las aves; entretanto la conversión alimenticia empeoró debido a los tratamientos con 0-6\% RASM comparado con el tratamiento Contr1. El color de la yema aumentó debido a la RASM. Conclusión: RASM puede ser incluido en dietas a base de sorgo para codornices en un $9 \%$, debido a la mejora en el color de la yema, además de no tener ningún efecto negativo en el desempeño productivo y calidad del huevo.

Palabras clave: Achiote; Bixa orellana; calidad del huevo; codorniz; Coturnix japonica; digestibilidad de nutrientes; huevo; nutrición de aves; pigmentación de yema; pigmento vegetal; semilla de achiote; subproducto; urucu.

\section{Resumo}

Antecedentes: O farelo residual da semente de urucum (RASM) é um subproduto da extração da bixina pela indústria cosmética e pode ser usado na alimentação animal. Objetivo: Dois experimentos foram conduzidos para determinar o valor nutritivo e os efeitos de inclusão do FRSU em dietas para codornas Japonesas. Métodos: Para o experimento de digestibilidade, 160 codornas Japonesas foram distribuídas em um estudo casualizado com dois tratamentos e 10 repetições com oito aves cada. Os tratamentos consistiram em uma dieta referência e uma dieta teste, a qual era composta por $75 \%$ da dieta referência e $25 \%$ de RASM. Para o ensaio de desempenho, 192 codornas Japonesas foram usadas em estudo ao acaso com seis tratamentos e quatro repetições com oito aves cada. Os tratamentos consistiram em uma dieta controle a base de milho (Contr1) e outra à base de sorgo com cantaxantina (Contr2) e quatro dietas a base de sorgo com níveis de inclusão de RASM (0, 3, 6 e 9\%). Resultados: Os coeficientes de digestiblidade de matéria seca e proteína bruta, coeficiente de metabolização da energia bruta e retenção de cálcio e fósforo foram 41,05; 43,12; 47,97; 25,49 e 30,35\%, respectivamente. A inclusão do FRSU não influenciou a produtividade das aves; entretanto, a conversão alimentar piorou devido aos tratamentos com 0-6\% FRSU comparado com o tratamento Contr1. A cor da gema aumentou devido ao FRSU. Conclusão: RASM pode ser incluido em dietas baseadas em sorgo para codornas em 9\%, devido a mehoria na cor da gema e nenhum efeito negativo no desempenho produtivo e qualidade de ovo.

Palavras-chave: Bixa orellana; codornas Japonesas; Coturnix japônica; digestibilidade de nutrientes; nutrição de aves; ovo; pigmentação de gema; pigmento vegetal; qualidade do ovo; semente de urucum; subproduto. 


\section{Introduction}

Nutrition plays an important role in quail productivity and egg quality. Sorghum can be used to replace corn (Moura et al., 2011). However, as sorghum is poor in carotenoids, it is necessary to add artificial pigments to the diet to enhance yolk color (Oliveira et al., 2008).

Residual annatto seed meal (RASM), a byproduct of bixin extraction (Santos et al., 2015), can be used in animal feed. Annatto seeds are externally covered by reddish pigments, primarily, carotenoids such as bixin and norbixin (Mantovani et al., 2013). Bixin is used as a coloring substance in the food, pharmaceutical, and cosmetic industries (Raddatz-Mota, 2017). The annatto grain residue has considerable nutritional value due to its high content of protein, fiber, and minerals (Queiroz et al., 2011). According to Rêgo et al. (2010), bixin extraction generates $98 \%$ of the byproduct, of which $97 \%$ is not reused. Brazil is one of the major producers and exporters of this coloring residue. According to several researchers, RASM could be included in feed for cattle (Rêgo et al., 2010), broilers (Souza et al., 2015), and laying hens (Garcia et al., 2014). The growing demand for natural colors makes RASM a profitable and viable alternative in agriculture because, in addition to economic considerations, the annatto plant has the advantage of adaptability and reasonable tolerance to drought (Ribeiro et al., 2013).

Therefore, this study was carried out to determine the nutritional value of RASM, as well as its effect on productivity and egg quality of laying quails.

\section{Materials and Methods}

\section{Ethical considerations}

The experimental protocol was approved by the Ethics Committee on Animal Use (protocol number 01/13; May 7, 2013) of Universidade de Rio Verde, Brazil.

\section{Digestibility experiment}

A total of 160 laying Japanese quails were used in this experiment. All individuals were 50 day-old females and were maintained in metallic cages $(33 \times 25 \times 20 \mathrm{~cm})$ for 10 days, with 5 days for adaptation to the diets and 5 days for excreta collection.

A completely randomized design was used, with two treatments, 10 replicates, and eight birds per experimental unit. Treatments consisted of a reference diet based on ground corn and soybean meal, and a test diet containing $75 \%$ of the reference diet and $25 \%$ RASM, w/w (Table 1). Diets were formulated in accordance with quail requirements (Rostagno et al., 2011) and, together with water, were provided ad libitum throughout the experimental period.

Table 1. Nutritional composition of the reference diet.

\begin{tabular}{lc}
\hline Ingredients & \% \\
\hline Corn & 53.22 \\
Soybean meal & 34.73 \\
Soybean oil & 2.48 \\
Dicalcium phosphate & 1.18 \\
Limestone & 6.93 \\
DL-Methionine & 0.28 \\
L-Lysine & 0.13 \\
Common salt & 0.34 \\
Premix ${ }^{l}$ & 0.50 \\
Inert & 0.20 \\
BHT & 0.01 \\
\hline Total & 100.00 \\
\hline Chemical composition & \\
Crude protein & 19.90 \\
Metabolizable energy $(\mathrm{kcal} / \mathrm{kg})$ & 2800 \\
Calcium & 3.00 \\
Available phosphorus & 0.33 \\
Sodium & 0.15 \\
Total lysine & 1.22 \\
Total methionine & 0.58 \\
\hline Each & \\
\hline
\end{tabular}

${ }^{I}$ Each kg feed contains: vit A: 9,000 IU; vit D3: 2,500 IU; vit E: 10 IU; vit K3: $1.8 \mathrm{mg}$; vit B12: $12 \mathrm{mcg}$; niacin: $25 \mathrm{mg}$; pantothenic acid: $10 \mathrm{mg}$; folic acid: $0.4 \mathrm{mg}$; thiamin: $1.5 \mathrm{mg}$; choline: $0.5 \mathrm{~g}$; riboflavin: $5 \mathrm{mg}$; pyridoxine: $1.5 \mathrm{mg}$; biotin: $0.04 \mathrm{mg}$; $\mathrm{Cu}: 10 \mathrm{mg}$; Fe: $40 \mathrm{mg}$; $\mathrm{I}: 1 \mathrm{mg}$; Mn: $0.075 \mathrm{~g}$; Se: $0.3 \mathrm{mg}$; Zn: $50 \mathrm{mg}$; methionine: $0.1 \mathrm{~g}$; chlorohydroxyquinoline: $30 \mathrm{mg}$; antioxidant: $2.5 \mathrm{mg}$. 
The total excreta collection method was used, with ferric oxide (1.0\%) as a fecal marker to indicate the start and end of the collection period. Excreta were collected twice a day (at 8 and $16 \mathrm{~h}$ ), packed, weighed, and stored in a freezer $\left(-18{ }^{\circ} \mathrm{C}\right)$ for later analysis. At the end of the experiment, these were defrosted, homogenized, and weighed again. Subsequently, they were dried in a forced-air oven at $55^{\circ} \mathrm{C}$ for $72 \mathrm{~h}$, ground, and packed again.

Excreta, diets, and RASM samples were analyzed for dry matter (DM), crude protein (CP), ether extract (EE), calcium (Ca), phosphorus $(\mathrm{P})$, crude fiber (CF), and gross energy (GE), based on the methods of Silva and Queiroz (2002). Apparent nutrient digestibility and apparent metabolizable energy (AME) were determined as follows:

$$
\operatorname{DCDM}(\%)=\frac{\mathrm{DM}_{\text {ingested }}-\mathrm{DM}_{\text {excreted }}}{\mathrm{DM}_{\text {ingested }}} \times 100
$$

$$
\mathrm{AME}=\frac{\mathrm{GE}_{\text {ingested }}-\mathrm{GE}_{\text {excreted }}}{\mathrm{DM}_{\text {ingeted }}}
$$

where DCDM stands for digestibility coefficient of dry matter, DM for dry matter, AME for apparent metabolizable energy, and $\mathrm{GE}$ is gross energy. The Matterson et al. (1965) formula was used to obtain the digestible nutrients from RASM:

$$
\mathrm{MEF}_{\mathrm{F}}=\mathrm{ME}_{\mathrm{RD}}+\frac{\mathrm{ME}_{\mathrm{TD}}-\mathrm{ME}_{\mathrm{RD}}}{\% \text { substitution }}
$$

where $\mathrm{ME}_{\mathrm{F}}$ stands for metabolizable energy of the feed, $\mathrm{ME}_{\mathrm{TD}}$ for metabolizable energy of the test diet, and $\mathrm{ME}_{\mathrm{RD}}$ for metabolizable energy of the reference diet.

\section{Performance experiment}

A total of 192 laying female Japanese quails were used in this experiment. All individuals were 50-days old, and were kept for 84 days divided into 3 cycles of 28 days each. The experimental design was completely randomized, with six treatments, four replicates, and eight birds per experimental unit. The treatments included a control diet based on corn (Contr 1), a basal diet based on sorghum (BD) containing an artificial pigment, canthaxanthin 10\% (Contr 2), BD with no RASM or artificial pigment, BD with $3 \%$ RASM, BD with $6 \%$ RASM, and BD with $9 \%$ RASM. The experimental diets were formulated according to the nutritional requirements for quails, as recommended by Rostagno et al. (2011) (Table 2). Photoperiod in the birdhouse was set at 17:7 h light: day schedule. Water and diets were provided ad libitum.

Feed intake, egg production, egg mass, feed conversion per egg mass and per dozen eggs, egg weight, egg $\mathrm{pH}$, specific gravity, yolk color, Haugh unit, yolk, albumen, and eggshell absolute and relative weight, yolk and albumen diameter and height, and eggshell thickness were assessed.

The egg production period was divided into three periods of 28 days each. At the end of each period, the feed left in each feeder was collected to calculate feed intake. Egg collection and mortality were recorded twice a day. Percent egg production was calculated by dividing the total amount of eggs per cage by the number of quails, correcting for mortality. The eggs of the last three days of each period were weighed individually to obtain the average weight of the eggs. Egg mass was the product of total egg production by the average weight of eggs per pen. Feed conversion per egg mass was the ratio of feed intake to egg mass, and feed conversion per dozen eggs was the ratio of feed intake to egg production, multiplied by 12 . 
Table 2. Nutritional composition of the experimental diets.

\begin{tabular}{lcccccc}
\hline & \multicolumn{5}{c}{ RASM level (\%) } \\
\cline { 2 - 7 } Ingredients (\%) & Contr1 & Contr2 & $\mathbf{0 . 0}$ & $\mathbf{3 . 0}$ & $\mathbf{6 . 0}$ & $\mathbf{9 . 0}$ \\
\hline Corn & 53.22 & 0.00 & 0.00 & 0.00 & 0.00 & 0.00 \\
Soybean meal & 34.73 & 33.54 & 33.54 & 33.38 & 33.22 & 33.09 \\
Soybean oil & 2.48 & 4.13 & 4.13 & 4.81 & 5.48 & 6.16 \\
Sorghum & 0.00 & 52.72 & 52.72 & 49.24 & 45.77 & 42.27 \\
RASM & 0.00 & 0.00 & 0.00 & 3.00 & 6.00 & 9.00 \\
Dicalcium phosphate & 1.18 & 1.14 & 1.14 & 1.14 & 1.13 & 1.13 \\
Limestone & 6.93 & 6.96 & 6.96 & 6.93 & 6.90 & 6.86 \\
DL-Methionine & 0.28 & 0.29 & 0.29 & 0.29 & 0.30 & 0.30 \\
L-Lysine & 0.13 & 0.18 & 0.18 & 0.17 & 0.16 & 0.15 \\
Common salt & 0.34 & 0.34 & 0.34 & 0.34 & 0.34 & 0.34 \\
Premix ${ }^{*}$ & 0.50 & 0.50 & 0.50 & 0.50 & 0.50 & 0.50 \\
Inert & 0.20 & 0.00 & 0.20 & 0.20 & 0.20 & 0.20 \\
Canthaxanthin 10\% & 0.00 & 0.20 & 0.00 & 0.00 & 0.00 & 0.00 \\
BHT & 0.01 & 0.01 & 0.01 & 0.01 & 0.01 & 0.01 \\
Total & 100 & 100 & 100 & 100 & 100 & 100 \\
\hline Chemical analysis (\%), DM basis & & & & & & 19.94 \\
\hline Crude protein & 19.90 & 19.90 & 19.90 & 19.91 & 19.92 & 19.94 \\
Metabolizable energy (kcal/kg) & 2800 & 2800 & 2800 & 2800 & 2800 & 2800 \\
Calcium & 3.00 & 3.00 & 3.00 & 3.00 & 3.00 & 3.00 \\
Available phosphorus & 0.33 & 0.33 & 0.33 & 0.33 & 0.33 & 0.33 \\
Sodium & 0.15 & 0.15 & 0.15 & 0.15 & 0.15 & 0.15 \\
Total lysine & 1.22 & 1.22 & 1.22 & 1.22 & 1.22 & 1.23 \\
Total methionine & 0.58 & 0.58 & 0.58 & 0.58 & 0.58 & 0.58 \\
Crude fiber & 2.76 & 2.99 & 2.99 & 3.42 & 3.85 & 4.29 \\
\hline
\end{tabular}

${ }^{I}$ Each kg of feed contains: vit A: 9,000 IU; vit D3: 2,500 IU; vit E: $10 \mathrm{IU}$; vit K3: $1.8 \mathrm{mg}$; vit B12: $12 \mathrm{mcg}$; niacin: $25 \mathrm{mg}$; pantothenic acid: $10 \mathrm{mg}$; folic acid: $0.4 \mathrm{mg}$; thiamin: $1.5 \mathrm{mg}$; choline: $0.5 \mathrm{~g}$; riboflavin: $5 \mathrm{mg}$; pyridoxine: $1.5 \mathrm{mg}$; biotin: $0.04 \mathrm{mg}$; Cu: $10 \mathrm{mg}$; Fe: $40 \mathrm{mg}$; $1 \mathrm{mg}$; Mn: $0.075 \mathrm{~g}$; Se: $0.3 \mathrm{mg}$; Zn: $50 \mathrm{mg}$; methionine: $0.1 \mathrm{~g}$; chloro hydroxyquinoline: $30 \mathrm{mg}$; antioxidant: $2.5 \mathrm{mg}$.

RASM -residual annatto seed meal; Contr1 - control diet based on corn; Contr2 -control diet based on sorghum.

Yolk and thick albumen diameter and height were measured with a digital caliper and a micrometer, respectively. Average eggshell thickness was determined at three locations (at both poles and in the middle) using a digital caliper with $0.001 \mathrm{~mm}$ precision (Digimess, São Paulo, SP, Brazil). Haugh units were obtained using the formula: $\mathrm{HU}=100 \times \log (\mathrm{H}-1,7 \times$ $\left.\mathrm{W}^{0.37}+7.6\right)$, where $\mathrm{H}$ is albumen height $(\mathrm{mm})$, and $\mathrm{W}$ is egg weight $(\mathrm{g})$. A colorimetric fan was used for yolk color evaluation, using five eggs from each replicate.

\section{Statistical analysis}

Productive performance and egg quality of the sorghum-based diets containing RASM were analyzed with ANOVA in ActionStat (Equipe Estatcamp, 2014). When the $\mathrm{F}$ test results were significant, the data were subjected to polynomial regression at 5\% probability and their means were compared to those of Contr 1 and Contr 2 treatments by the Dunnett test, at 5\% probability. 


\section{Results}

The nutrient composition of RASM is listed in Table 3.

Table 3. Nutrient composition and gross energy of residual annatto seed meal (RASM).

\begin{tabular}{lc}
\hline \multicolumn{1}{c}{ Parameter } & Value \\
\hline Dry matter (DM, \%) & 90.20 \\
Crude protein (CP, \%) & 13.13 \\
Ether extract (EE, \%) & 2.10 \\
Crude fiber (\%) & 17.33 \\
Neutral detergent fiber (NDF, \%) & 34.80 \\
Acid detergent fiber (ADF, \%) & 21.45 \\
Calcium (Ca, \%) & 0.51 \\
Total phosphorus (P, \%) & 0.40 \\
Gross energy (GE, kcal/kg) & 3836 \\
\hline
\end{tabular}

Nutrient utilization and energy results are presented in Table 4.

Table 4. Use of nutrients and energy from residual annatto seed meal (RASM) by Japanese quails, based on dry matter data.

\begin{tabular}{lc}
\hline \multicolumn{1}{c}{ Parameter (\%) } & Value \\
\hline Digestible dry matter & 37.02 \\
DC of dry matter & 41.05 \\
& \\
Digestible protein & 5.66 \\
DC of crude protein & 43.12 \\
& \\
Digestible ether extract & 1.04 \\
DC of ether extract & 49.40 \\
& \\
Retained calcium & 0.13 \\
Calcium retention & 25.49 \\
& \\
Retained phosphorus & 0.12 \\
Phosphorus retention & 30.35 \\
& \\
Apparent metabolizable energy $(\mathrm{kcal} / \mathrm{kg})$ & 1840 \\
MC of gross energy & 47.97 \\
\hline
\end{tabular}

$\mathrm{DC}=$ digestibility coefficient $\mathrm{MC}=$ metabolization coefficient.
The RASM inclusion level in the diets did not influence ( $p>0.05$ ) feed intake, egg weight, laying rate, egg mass, or feed conversion, and these results did not differ $(\mathrm{p}>0.05)$ from those obtained with diets containing canthaxanthin. However, compared with the corn-based treatment, feed conversion of birds fed diets with 0,3 , and $6 \%$ RASM was worse (Table 5).

The increasing levels of RASM inclusion in the diets did not affect ( $>0.05)$ egg quality parameters (Table 6), except for yolk color, which increased linearly $(\mathrm{p}<0.05)$ in 0.86 points for each 1\% RASM inclusion.

\section{Discussion}

The moisture content of RASM $(9.80 \%)$ follows the recommended values for meals used for animals in Brazil, which is $12 \%$ maximum (Brasil, 2007). The DM content was similar to the $88.8 \%$ described by Tonani et al. (2000); however, our results revealed values higher than $85.80 \%$ reported by Lima Jr et al. (2014) and slightly lower than $92.43 \%$ reported by Carvalho et al. (2009).

Proteins are structural and functional components in cells; they have immunological functions, participate in hormone production, and catalyze organic reactions (De Angelis \& Tirapegui, 2007). Tonani et al. (2000) reported similar values for CP in RASM (13.5\%); however, Kumar et al. (2007) reported a higher value $(14.40 \%)$. Valério et al. (2015) found a value lower $(11.50 \%)$ than the one obtained in the present study.

Kumar et al. (2007) and Valério et al. (2015) found $\mathrm{EE}$ values close to those obtained in this study $(2.00 \%$ and $2.23 \%$, respectively). Regarding GE, Valério et al. (2015) obtained a lower value $(2,345 \mathrm{kcal} / \mathrm{kg})$. These differences may be related to the pigment extraction method and seed processing by the cosmetic industries and consequent RASM production. 
Table 5. Performance of quails fed diets containing residual annatto seed meal (RASM).

\begin{tabular}{lccccccc}
\hline \multirow{2}{*}{\multicolumn{1}{c}{ Parameters }} & \multirow{2}{*}{ Contr1 } & \multirow{2}{*}{ Contr2 } & \multicolumn{4}{c}{ RASM levels (\%) } & \multirow{2}{*}{ CV(\%) } \\
\cline { 5 - 7 } & & & 0.0 & 3.0 & 6.0 & 9.0 & \\
\hline Feed intake (g/d) & 31.34 & 31.23 & 31.07 & 27.35 & 29.63 & 28.65 & 5.53 \\
Feed conversion (kg/kg) & 3.22 & 3.56 & $3.87^{*}$ & $3.55^{*}$ & $3.85^{*}$ & 3.07 & 6.29 \\
Feed conversion (kg/dozen) & 0.42 & 0.46 & $0.48^{*}$ & $0.45^{*}$ & $0.51^{*}$ & 0.40 & 5.56 \\
Egg weight (g) & 10.88 & 10.68 & 10.38 & 10.70 & 11.18 & 10.93 & 4.73 \\
Laying rate (\%) & 83.83 & 84.73 & 84.49 & 91.30 & 82.65 & 91.31 & 6.09 \\
Egg mass (g/bird/d) & 9.13 & 9.08 & 8.87 & 9.75 & 9.28 & 10.00 & 5.79 \\
\hline
\end{tabular}

$\mathrm{CV}$ : Coefficient of variation.

Means followed by an asterisks (*) differ from Contr1 treatment by Dunnett test at $5 \%$ probability.

Table 6. Egg quality of quails fed diets containing residual annatto seed meal (RASM).

\begin{tabular}{|c|c|c|c|c|c|c|c|}
\hline \multirow{2}{*}{ Parameters } & \multirow{2}{*}{ Contr1 } & \multirow{2}{*}{ Contr2 } & \multicolumn{4}{|c|}{ RASM levels (\%) } & \multirow[t]{2}{*}{$\mathrm{CV}(\%)$} \\
\hline & & & 0.0 & 3.0 & 6.0 & 9.0 & \\
\hline Yolk weight (g) & 3.34 & 3.17 & 3.37 & 3.16 & 3.39 & 3.40 & 5.94 \\
\hline Yolk percentage (\%) & 30.74 & 29.64 & 32.43 & 29.46 & 30.64 & 31.11 & 6.35 \\
\hline Yolk height (mm) & 11.87 & 12.25 & 12.00 & 11.87 & 12.25 & 12.13 & 3.93 \\
\hline Yolk diameter (mm) & 23.50 & 22.75 & 23.63 & 23.25 & 23.25 & 24.00 & 4.77 \\
\hline Yolk index & 0.506 & 0.538 & 0.509 & 0.511 & 0.528 & 0.506 & 4.25 \\
\hline Yolk color $^{l}$ & 4.70 & 12.21 & $4.30 * *$ & $5.77 * *$ & $10.90^{*}$ & $11.15^{*}$ & 12.46 \\
\hline Albumen weight (g) & 6.79 & 6.71 & 6.23 & 6.77 & 7.03 & 6.76 & 5.38 \\
\hline Albumen percentage $(\%)$ & 62.37 & 62.76 & 59.98 & 63.29 & 62.53 & 61.81 & 5.00 \\
\hline Albumen height (mm) & 4.63 & 5.00 & 5.00 & 4.50 & 4.63 & 4.50 & 5.48 \\
\hline Albumen diameter (mm) & 45.00 & 41.37 & 41.00 & 44.13 & 42.87 & 43.87 & 4.82 \\
\hline Albumen index & 0.103 & 0.122 & 0.122 & 0.102 & 0.108 & 0.103 & 6.11 \\
\hline Haugh unit & 90.86 & 92.91 & 93.24 & 90.33 & 90.68 & 90.21 & 2.42 \\
\hline Eggshell weight (g) & 0.75 & 0.81 & 0.78 & 0.77 & 0.76 & 0.77 & 6.75 \\
\hline Eggshell percentage (\%) & 6.89 & 7.60 & 7.58 & 7.24 & 6.83 & 7.08 & 5.11 \\
\hline Eggshell thickness (mm) & 0.204 & 0.210 & 0.203 & 0.208 & 0.204 & 0.212 & 5.74 \\
\hline Specific gravity (g/cm3) & 1.057 & 1.055 & 1.062 & 1.061 & 1.060 & 1.061 & 3.83 \\
\hline
\end{tabular}

CV: Coefficient of variation.

${ }^{l}$ Linear effect $\left(\hat{\mathrm{Y}}=4.18+0.86 \mathrm{x}, \mathrm{r}^{2}=0.77\right)$.

Means followed by an asterisk $(*)$ and two asterisks $(* *)$ differ from Contr 1 and Contr2, respectively, by Dunnett test at $5 \%$ probability.

Fiber is very important for gut function and fecal moisture maintenance, and RASM is relatively high in fiber $(17.33 \%)$, whichis close to the 15 and $16 \%$ reported by Tonani et al. (2000) and Bressani (1983), respectively.

RASM is a rich source of minerals. Its $\mathrm{Ca}$ and $\mathrm{P}$ content were higher than those of other feeds described by Rostagno et al. (2011), such as corn $(0.03 \% \mathrm{Ca}$ and $0.25 \% \mathrm{P})$ and sorghum $(0.03 \% \mathrm{Ca}$ and $0.26 \% \mathrm{P})$; however, the $\mathrm{Ca}$ and $\mathrm{P}$ content were different from $0.04 \% \mathrm{Ca}$ and 0.70\% P obtained by Kumar et al. (2007).

It is possible that the low digestibility coefficients of DM, CP and EE, mineral retention, and use of gross energy found in this study were caused by the high crude fiber 
in RASM (17.33\%), which has the ability to accelerate gastric emptying, reduce enzymatic activity and nutrient uptake, and decrease nutrient absorption because of its interactions with the intestinal mucosa (Müller et al., 2018).

None of the nutrients showed a high digestibility coefficient. However, the values in this study were close to those obtained with other byproducts used in bird diets, such as wheat bran and defatted rice bran, which showed very similar energy metabolization coefficients and metabolizable energy values (48.82 and 50.72\% and 1,911 and $1,897 \mathrm{kcal} / \mathrm{kg}$, respectively; Rostagno et al., 2011). Although RASM has high gross energy value, it becomes evident that this energy has little advantage for quails, as there is an inverse relationship between fiber content and nutrient digestibility (Pagnussatt $e t$ $a l ., 2011)$, and consequently, energy utilization.

The low protein utilization, and $\mathrm{Ca}$ and $\mathrm{P}$ retention observed could also have been caused by fiber quality, because crude fiber content in RASM is similar to the values reported for wheat bran and defatted rice bran; however, the digestible protein content in the latter feedstuffs is higher (12.03 and $11.88 \%$, respectively) according to Rostagno et al. (2011). Acid detergent fiber (ADF) is the indigestible fraction of crude fiber, which may influence nutrient digestibility (Gomes, 1996). The ADF value in RASM $(21.45 \%)$ was higher than that in wheat and rice bran (13.64 and 15.80\%, respectively; Rostagno et al., 2011). The different processing methods of the feedstuffs or the existing differences among the tested animal species result in different levels of nutrient use from a feed.

The amino acid availability in sorghum, such as that of lysine and methionine, is lower compared to corn (Moughan et al., 2014) because endosperm protein is more adherent to the starch granules in sorghum than in corn (Sedghi et al., 2013), which may have contributed to the poor feed conversion of diets containing sorghum and RASM at 3 and $6 \%$, relative to the treatment with corn.
In the treatment containing sorghum $+9 \%$ RASM, feed conversion values were similar to those obtained for corn-based diets. Sorghum contains tannins (low level), phytate, kafirin, and polyphenols that may have anti-nutritional effects (McCuistion et al., 2018), causing lower digestibility and nitrogen retention rates (Pasquali et al., 2017) relative to cornbased diets. However, these effects may have been mitigated by a lower ratio of sorghum and higher oil level relative to corn-based diets. Oil improves nutrient digestibility and increases lipase activity (Polycarpo et al., 2014). According to Kil and Stein (2011), oil inclusion in pig diets improves digestibility of most amino acids, which is attributed to the ability of oil to increase gastric emptying time and to reduce passage rate, which, in turn, increases the time for protein digestion and amino acid absorption.

RASM inclusion did not have an effect on feed intake probably due to the diets being iso-nutritive, ensuring the same nutritional and energetic density in all treatments. Similarly, Silva et al. (2006), when assessing RASM in diets for laying hens, did not observe differences in productive performance and recommended $12 \%$ RASM inclusion in the diet.

RASM's carotenoids intensified yolk color through xanthophyll -a group of carotenoid pigments- deposition. These results depend on the amount of pigment used in the diet, the deposition rate in the tissues, and the ability of birds to digest, absorb, and metabolize the pigment (Klassing, 1998). Free carotenoids are absorbed with fatty acids, dissolved in the micelles (Abdel-Aal et al., 2013), and transported by lipoproteins in the blood. Carotenoid transport depends on several factors, such as peripheral tissue demand, chemical properties of carotenoids, affinity of carotenoids for receptors and transporters, and ability of lipid vesicles to cross membranes in the liver and egg. Livers and eggs act as storage tissues (Moreno et al., 2016). 
Absence $(0 \%)$ or $3 \%$ RASM inclusion in the sorghum-based diets promoted a yolk color similar to that of corn-based diets; however, 6 and 9\% RASM inclusion resulted in a yolk color comparable to that of diets containing canthaxanthin, allowing us to infer that RASM could be used to enhance yolk pigmentation in quails.

Similar results were reported by Braz et al. (2007) and Garcia et al. (2014) when researching RASM levels from 0.5 to $2.5 \%$ for laying hens; showing no differences in egg quality, with the exception of yolk color, which increased with RASM use. Garcia et al. (2010) and Laganá et al. (2011) studied the inclusion of annatto seeds in diets of laying hens and detected an improvement in yolk color.

The RASM used contained $37.02 \%$ digestible dry matter, $5.66 \%$ digestible protein, $1.04 \%$ digestible ether extract, $0.13 \%$ retained calcium, $0.12 \%$ retained phosphorus, and $1,840 \mathrm{kcal} / \mathrm{kg}$ apparent metabolizable energy for quails. Thus, RASM may be included at $9 \%$ concentration in sorghum-based diets of laying quails, resulting in improved yolk color and no negative effects on bird productivity or egg quality.

\section{Declarations}

\section{Author contributions}

Pimentel-Mani performed the experiment and collaborated drafting the manuscript; Oliveira was involved in planning and supervising the work, processing the data and reviewing the paper; Lima-Dóro collected the data and performed laboratory analysis; Carneiro-Martins collected the data and worked on the manuscript; Souza-Júnior aided in interpreting the results.

\section{Conflicts of interest}

The authors declare they have no conflicts of interest with regard to the work presented in this report.

\section{References}

Abdel-Aal El-SM, Akhtar H, Zaheer K, Ali R. Dietary sources of lutein and zeaxanthin carotenoids and their role in eye health. Nutrients 2013; 5(4):1169-1185. DOI: https://doi.org/10.3390/nu5041169

Brasil - Padrões mínimos de matéria prima destinadaà alimentação animal -Anexo I. Portaria n. 7 de 09 de novembro de 1988. Publicado no Diário Oficial da União em 14/11/1988 http://sistemasweb.agricultura.gov.br/ arquivosislegis/anexos/rb/POR7 88 SFA MAPA.pdf

Braz NM, Fuentes MFF, Freitas ER, Sucupira FF, Moreira RF, Lima RC. Semente residual do urucum na alimentação de poedeiras comerciais: desempenho e características dos ovos. Acta Sci Anim Sci 2007; 29(2):33-129. DOI: http://dx.doi.org/10.4025/actascianimsci.v29i2.207

Bressani R. Chemical composition, amino acid content and nutritive value of protein of the annatto seed (Bixa orellana). Arch Latinoam Nutr 1983; 33(2):356-376.

Carvalho AV, García NHP, Farfán JA, Wada JKA. Caracterização de concentrado e isolado proteico extraído de sementes de cupuaçu (Theobroma grandiflorum, Schum). Braz J Food Technol 2009; 12(1):1-8. DOI: http://dx.doi.org/10.4260/BJFT2009050600001

De Angelis RC, Tirapegui J. Fisiologia da nutrição humana: aspectos básicos, aplicados e funcionais. 2a ed., São Paulo: Atheneu, 2007.

Equipe Estatcamp. Software Action. Estatcamp - Consultoria em estatística e qualidade. São Carlos, SP, Brasil. 2014.

Garcia EA, Molino AB, Gonçalves HC, Junqueira OM, Pelícia K, Osera RH, Duarte KF. Ground annatto seeds (Bixa orellana L.) in sorghumbased comercial layer diets and their effects on performance, egg quality, and yolk pigmentation. Rev Bras Cienc Avic 2010; 12(4):259-264. DOI: http://dx.doi.org/10.1590/S1516-635X2010000400007 
Garcia ERM, Cruz FK, Souza RPP, Feliciano WB, Ávila LR, Rohod RV. Desempenho e qualidade dos ovos de poedeiras alimentadas com semente de urucum. Arq Ciênc Vet Zool Unipar 2014; 18(1):17-20. DOI: https://doi.org/10.25110/arqvet.v18i1.2015.5364

Gomes JDF, Fukushima RS, Gomide CA, Sobral PJA, Lima CG, Putrino SM. Efeitos do incremento de fibra dietética sobre digestibilidade, desempenho e características de carcaça: II. Fêmeas suínas em pré-puberdade e puberdade. Semina: Ciênc Agrar 2007; 28(4):727-738. DOI: http://dx.doi.org/10.5433/1679-0359.2007v28n4p727

Kil DY, Stein HH. Dietary soybean oil and choice white grease improve apparent ileal digestibility of amino acids in swine diets containing corn, soybean meal, and distillers dried grains with solubles. Rev Colom Cienc Pecu 2011; 24(3):248-253. http://www.scielo.org.co/pdf/rccp/v24n3/ v24n3a03.pdf

Klassing KC. Comparative avian nutrition. New York: CAB International, 1998.

Kumar PS, Reddy YR, Ramesh S, Gobinath S, Ramana DBV. Nutritional evaluation of pigment extracted annatto seed meal. Indian J Anim Nutr 2007; 24(3):182-184. http://www.indianjournals.com/ijor.aspx?targe

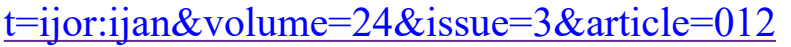

Laganá C, Pizzolante CC, Saldanha ESPB, Moraes JE. Turmeric root and annatto seed in secondcycle layer diets: performance and egg quality. Rev Bras Cienc Avic 2011; 13(3):171-176. DOI: http://dx.doi.org/10.1590/S1516-635X2011000300002

Lima Jr DM, Carvalho FFR, Clementino RH, Batista AMV, Maciel MV, Ferreira JCS, Pereira Neto JD. Performance of sheep fed on annatto byproduct. Ital J Anim Sci 2014; 13(3):563-567. DOI: https://doi.org/10.4081/ijas.2014.3147

Mantovani NC, Grando MF, XavierA, Otoni WC. Avaliação de genótipos de urucum (Bixa orellana L.) por meio da caracterização morfológica de frutos, produtividade de sementes e teor de bixina. Ciênc Florest 2013; 23(2):355-362. DOI: http://dx.doi.org/10.5902/198050989281

Matterson LD, Potter LM, Stutuz NW. The metabolizable energy of feed ingredient for chickens. Res Rep 1965; 7:3-11.

McCuistion KC, Selle PH, Liu SY, Goodband RD. Sorghum as a feed grain for animal production. In: Taylor JRN, Duodu KG, editors. Sorghum and Millets. Chemistry Technology and Nutritional Attributes. 2nd ed. Amsterdam: Elsevier, 2018. p.355-391.

Moreno JÁ, Díaz-Gómez J, Nogareda C, Ângulo E, Sandmann G, Portero-otin M, Serrano JCE, Twyman RM, Capell T, Zhu C, Christou P. The distribution of carotenoids in hens fed on biofortified maize is influenced by feed composition, absorption, resource allocation and storage. Sci Rep 2016; 6: article number 35346. DOI: http://doi.org/10.1038/srep35346

Moughan PJ, Ravindran V, Sorbara JOB. Dietary protein and amino acids consideration of the undigestible fraction. Poult Sci 2014; 93(9):2400-2410. DOI: https://doi.org/10.3382/ps.2013-03861

Moura AMA, Takata FN, Nascimento GR, Silva AF, Melo TV, Cecon PR. Pigmentantes naturais em rações à base de sorgo para codornas japonesas em postura. R Bras Zootec 2011; 40(11):2443-2449. DOI: http://dx.doi.org/10.1590/S1516-35982011001100023

MüllerM, Canfora EE,BlaakEE. Gastrointestinal transit time, glucose homeostasis and metabolic health: modulation by dietary fibers. Nutrients 2018; 10(3): article 275. DOI: https://doi.org/10.3390/nu10030275

Oliveira NTE, Fonseca JB, Soares RTRN, Ferreira KS, Thiébaut JTL. Pigmentação de gemas de ovos de codornas japonesas alimentadas com rações contendo colorífico. Ciênc Agrotec 2008; 31(5):1525-1531. DOI: http://dx.doi.org/10.1590/S1413-70542007000500038

Pagnussatt FA, Garda-Buffon J, Gutkoski LC, Badiale-Furlong E. Propriedade das frações 
proteicas de cultivares de arroz, aveia e trigo. Rev Inst Adolfo Lutz 2011; 70(2):185-192. http://www.ial.sp.gov.br/resources/insitutoadolfo-lutz/publicacoes/rial/10/rial70_2 completa/1362.pdf

Pasquali GAM, Fascina VB, Silva AL, Aoyagi MM, Muro EM, Serpa PG, Berto DA, Saldanha ESPB, Sartori JR. Maize replacement with sorghum and a combination of protease, xylanase, and phytase on performance, nutrient utilization, litter moisture, and digestive organ size in broiler chicken. Can J Anim Sci 2017; 97(2):328-337. DOI: http://dx.doi.org/10.1139/cjas-2016-0133

Polycarpo GV, Cruz VC, Alexandre NC, Fascina VB, Souza IMGP, Cravo JCM, Albuquerque R, Sartori JR, Pezzato AC. Effect of lipid sources and inclusion levels in diets for broiler chickens. Arq Bras Med Vet Zootec 2014; 66(2):519-528. DOI: http://dx.doi.org/10.1590/1678-41626629

Queiroz AJM, Dantas HJ, Figueirêdo RMF, Melo KS. Solar drying of jack fruit almonds. Eng Agric 2011; 31(6):1150-1161. DOI: http://dx.doi.org/10.1590/S0100-69162011000600012

Raddatz-Mota D, Pérez-Flores LJ, Carrari F, Mendoza-Espinoza JÁ, León-Sánchez FD, Pinzón-López LL, Godoy-Hernández G, Rivera-Cabrera F. Achiote (Bixa orellana L.): a natural source of pigment and vitamin E. J Food Sci Technol 2017; 54(6):1729-1741. DOI: https://doi.org/10.1007/s13197-017-2579-7

Rêgo AC, Cândido MJD, Pereira ES, Feitosa JV, Rêgo MMT. Degradação de silagens de capimelefante contendo subproduto do urucum. Rev Ciênc Agron 2010; 41(3):482-489. DOI: http://dx.doi.org/10.1590/S1806-66902010000300023

Ribeiro AEL, Castellani MA, Moreira AA, Perez-Maluf R, Silva CGV, Santos AS. Diversidade e sazonalidade de crisopídeos (Neuroptera: Chrysopidae) em plantas de urucum. Hortic Bras 2013; 31(4):636-641. DOI: http://dx.doi.org/10.1590/S0102-05362013000400021

Rostagno HS, Albino LFT, Hannas MI, Donzele JL, Sakomura NK, Perazzo FG, Saraiva A, Abreu
MLT, Rodrigues PB, Oliveira RF, Barreto SLT, Brito CO. Tabelas brasileiras para aves e suínos: composição de alimentos e exigências nutricionais. $4^{\mathrm{a}}$ ed. Viçosa: Editora Universitária, 2017.

Santos DC, Queiroz AJM, Figueirêdo RMF, Oliveira ENA. Sun drying of residual annatto seed powder. Acta Sci - Technol 2015; 37(1):161-166. DOI: http://dx.doi.org/10.4025/actascitechnol.v37i1.20582

Sedghi M, Ebadi MR, Golian A, Ahmadi H. Prediction of digestible amino acid and true metabolizable energy contents of sorghum grain from total essential amino acids. J Agric Sci 2013; 151(5):693-700. DOI: https://doi.org/10.1017/S0021859612000329

Silva DJ, Queiroz AC. Análise de alimentos. Métodos químicos e biológicos. $3^{\mathrm{a}}$ ed., Viçosa: Editora Universitária, 2002.

Silva JHV, Silva EL, Jordão Filho J, Ribeiro MLG, Costa FGP. Resíduo da semente de urucum (Bixa orellana L.) como corante da gema, pele, bico e ovário de poedeiras avaliado por dois métodos analíticos. Ciênc Agrotec 2006; 30(5):988-994. DOI: http://dx.doi.org/10.1590/S1413-70542006000500024

Souza DH, Freitas ER, Santos EO, Cipriano RM, Figueiredo CWS, Dantas FDT. Inclusion of annatto seed by-product in diets containing sorghum for slow-growth broilers. Ciênc Agrotec 2015; 39(3):248-259. DOI: http://dx.doi.org/10.1590/S1413-70542015000300006

Tonani FL, Ruggieri AC, Guim A, Andrade P, Queiroz AC, Santos HQ, Malheiros EB. Avaliação nutricional do resíduo de urucum (Bixa orellana, L.) após a extração do corante. ARS Vet 2000; 16(2):118-121. http://www.arsveterinaria.org.br/ arquivo/2000/v.16,\%20n.2,\%202000/118-121.pdf

Valério MA, Ramos MIL, Braga Neto JÁ, Macedo MLR. Annato seed residue (Bixa orellana L.): nutritional quality. Food Sci Technol 2015; 35(2):326-330. DOI: http://dx.doi.org/10.1590/1678-457X.6539 